\title{
CAPACIDADE DE COMBINAÇÃO DE LINHAGENS OBTIDAS PELO MÉTODO DE DIHAPLOIDIZAÇÃO NA CULTURA DO MILHO
}

\section{CAPACITY OF COMBINATION OF OBTAINED LINEAGES FOR THE METHOD OF DIHAPLOIDIZATION IN THE CORN CULTURE}

\author{
Maria Aildes de FREITAS \\ Orientador(a): Prof. Dr. Pedro RONZELLI JÚNIOR \\ (Departamento de Fitotecnia e Fitossanitarismo)
}

\begin{abstract}
RESUMO
Nove linhagens endogâmicas obtidas pelo método de dihaploidização foram submetidas a um top cross com dois testadores de base genética estreita e os híbridos simples foram avaliados em dois locais, na região dos Campos Gerais, PR. Este estudo teve por objetivo avaliar a capacidade geral de combinação (CGC) e a capacidade específica de combinação (CEC) de linhagens obtidas pelo método de dihaploidização e verificar se elas são promissoras na obtenção de híbridos de milho comercialmente competitivos. Os experimentos foram instalados em delineamento de blocos casualizados com três repetições, incluindo duas testemunhas comerciais, sendo as duas linhagens que compõem esses híbridos comerciais utilizadas como testadores. As parcelas foram constituídas de duas linhas de 5,0 m espaçadas de $0,80 \mathrm{~m}$, cuja densidade populacional de plantas era de 62.000 plantas por hectare. As variáveis avaliadas foram: rendimento de grãos, altura de planta, altura de inserção de espiga e severidade da doença ferrugem comum (Puccina sorghi). Estimaram-se os efeitos da CGC e CEC das linhagens dihaplóides. A análise conjunta de variância das variáveis estudadas mostrou efeitos altamente significativos $(P<0,01)$ com relação à $C G C$ das linhagens para todas as variáveis analisadas, entretanto para $C G C$ dos testadores, efeitos significativos só foram observados para a variável rendimento de grãos e altura de inserção de espiga. O efeito significativo da capacidade específica de combinação foi manifestado apenas para altura de planta e altura de inserção de espiga. $\mathrm{Na}$ interação Local $x$ Tratamentos foram verificadas diferenças altamente significativas para todas as variáveis analisadas, sendo assim, as médias obtidas em cada local foram submetidas a um teste de comparação de médias. Na interação Local $x F_{1}$ 's houve diferenças altamente significativas para a CGC das linhas, sendo estas somente manifestadas para as variáveis rendimento de grãos e altura de inserção de espiga. Quanto a CGC dos Testadores x Local houve efeito significativo para altura de planta e altura de inserção de espiga. Quanto a CEC x Local não houve diferença significativa $(P>0,01)$. Esses resultados indicam influência maior dos efeitos gênicos aditivos. As linhagens apresentaram comportamento diferenciado para cada variável analisada, para CGC os maiores efeitos foram das linhagens $L 1, L 2, L 3, L 4$ e L7 e o efeito da CEC apresentou os maiores valores nos cruzamentos $L 5 \times T$, para rendimento de grãos, $\mathrm{L} 3 \times \mathrm{T}_{1}$, para altura de planta e $\mathrm{L} 1 \times \mathrm{T}_{2}$ e para altura de inserção de espiga. ACGC dos testadores mostrou comportamento diferenciado entre as variáveis e entre os locais.
\end{abstract}

Palavras-chave: Zea mays, dihaplóides, capacidade combinatória, top cross, linhas endogâmicas.

\begin{abstract}
Nine inbred lines obtained by dihaploidization, were evaluated in a top cross with two testers of narrow genetic bases and the single-cross hybrids were tested in two location, at the Campos Gerais region, PR. The objective was to examine the General Combining Ability (GCA) and the Specific Combining Ability (SCA) of the lines obtained by haploidization and to verify how promising they are to obtain commercial competitive maize hybrids. The experiments were settled in randomized complete block design with three replications, including two commercial controls, as being the lines that compose these commercial hybrids used as controls. The experimental plots consist of two $5.0 \mathrm{~m}$ rows spaced at $0.8 \mathrm{~m}$, with 62,000 density plants per hectare. The variables estimated were grain yield, plant height, ear height and resistance of the disease common rust (Puccinia sorghi). General and specific combining ability effects (GCA and SCA) were determined for the doubled-haploids lines. The treatments combined analyses showed high statistic significance $(P<0.01)$ to GCA. However, the GCA of the controls showed only significant effects for grain yield and ear high. The statistical significant effect of the SCA was only showed for the plant high and ear high. The interaction Location $x$ Treatment showed high statistic significant differences for all analyzed variables. The Location $x F_{\text {, }}$ s interaction showed high statistic significant differences for GCA for grain yield and ear high. The GCA of Testers $x$ Location showed statistic significant effects for the plant high and the ear high. The SCA $x$ Location interaction did not present statistic significant differences $(P<0.01)$. These results showed greater influence of the additive gene effects. The lines showed a different behavior for each analyzed variable, with the major effects for GCA obtained within the lines L1, L2, L3, L4 and $L 7$ and for SCA obtained within the crosses $L 5 X T_{1}$ for grain yield, $L 3 \times T_{1}$, for plant hight, and $L 1 \times T_{2}$ for ear high. The controls GCA showed different behavior among treatments and locations.
\end{abstract}

Key-words: Zea mays, double-haploids, combining ability, top cross, inbred lines 